\title{
The Issue of North Korean women by examining gender awareness of female defectors*
}

\author{
Lee, Mi-kyung \\ (Education Center for Unification)
}

$\langle$ CONTENTS〉

I. Introduction

II. The issues of North Korean Women

1. Gender Awareness of North Korean Women

2. The change of North Korea women' s awareness and its limit
III. State and Woman

1. North Korean Women under patriarchal socialism

2. The North Korea's policy on women: paralyzing awareness

IV. Conclusion

- Keyword: the North Korea's policy on women, gender awareness, patriarchy, double works, the structure of division of labour by gender

\section{【ABSTRACT】}

This paper started from the question whether they have an equal status and awareness corresponding to their public participation and to figure out their problem and the origin of it. Apparently, North Korean women have participated in public affairs under the legal and systemic supports based on equality of both genders. However, they also had to take full responsibility in household work due to the political system which is based on patriarchism. In addition, their social status does not reflect the principle of equality of both genders since most of the women's jobs are concentrated on low-waged and subordinate position.

However, their actual problems expand to their lack of awareness about their surroundings that they face. It is witnessed in the interviews with the female defectors- North Korean women accept their realities of life without discontent.

* The terminology "gender awareness" is used comprehensively to explain the social relationship between men and women, and social awareness. The concept "gender" is distinguished from the meaning of biological "sex" that is used to divide male and female that is learned by society. Therefore this thesis use the terminology "gender awareness" 
The North Korean women had no critical sense toward double burden and gender, and such a status has not changed much even after the economic difficulties caused to change their life. This current situation of North Korean women is derived from the characteristics of the political system-patriarchical socialism- \& the North Korea's policy on women adhered actual discrimination causing women' s subordinate position \& passive awareness.

\section{I . Introduction}

What is the issues of North Korean women? First of all, they could be estimated by whether the women of North Korea have lived achieving what they want under equal social status. According to existing studies, although women participate in the labor force outside the home under the principle of gender equality, North Korean women are burdened much more since their status has not improved corresponding to their participation in social activities. ${ }^{1)}$ As mentioned in the studies, they have combined their career and their role as a traditional women to abide by their duties and maintain their livelihoods not to enhance their rights or realize their ideals.

However, the more critical issue in North Korean women is not just they have the double burden under the discriminatory social structure, but rather they are uncritical on the discrimination against women. This is testified the fact there has not been any social movement or effort to enhance the status of women as same as other socialist regimes in North Korea. This is reassured the fact that the North Korea's female defectors regard their dual burden by their social activities and the role of traditional women as a matter of course. ${ }^{2)}$

1) The mainstream of the researches including the above studies on North Korean women aim at analyzing whether North Korean women establish gender equality corresponding to the principle of socialism. And majority of the studies states that North Korean women are subordinate to patriarchal Confucianism. Tae-young Lee (1979, 1981,1988); Hyun-sun Park(1988); Hyung Cho(1992); Minister without portfolio room(1990); In-suk Nam(1992); Sunwook Kim(1992); Korean women's Development Institute(1992); Bong-suk Sohn(1993); Sookjae Moon(1994); Keum-soon Lee(1996); Hyun-baek Jung(2001); Korean women's Society Institute(2001); Ewha Women's Studies(2001).

2) Majority of female defectors that came to South Korea have taken division of work corresponding to their gender for granted regardless of their education and social status. They constantly say "This is tradition of korean, grandmothers and mothers did as well..." accepting these burdens as their inevitable duties although there could be some discontent. 
The uncritical sense of North Korean women toward double burden and gender has not changed much even after the economic difficulties which had caused changes in their home life. As the economic difficulties ceased the supply of social services, women had to take the major responsibilities of the living of their families. ${ }^{3)}$ During this process, the sense of women that household affairs and childcare entirely belongs to women has been changed, and their spouses also recognized the change and helped their wives. However, there are limitations since they did not deny patriarchism and even did not show their will to change their situation. ${ }^{4)}$

Considering these, the more serious problem of North Korean women is their lack of critical awareness toward that rather than their double burden apart from the realization of their ideals. Because the lack of awareness of their situation make the prospect for the development of their status darker. The Problems of North Korean Women are derived from the political culture that considers the burden on women as a natural one. And several laws that guarantees gender equality and social measures to assist women do social work and housework simultaneously blocked the necessity for their social enhancement of North Korean Women's right and status. That is just paternal patriarchal socialism, one of the features of the North Korean system which forbids the North Korean Women to criticism.

This research aims to figure out the issue of North Korean women by examining gender awareness of female defectors from North Korea; the reason and the aspect of this issue. Therefore, it will analyze series of polices and measures to women taken by the North Korean authorities. During the process, it will also examine women's current situation such as the degree of their social status and awareness. Finally, it will present how the problems of North Korean women could be resolved based on the research.

In order to analyze the above issues, this study reviewed the literatures and carried out in-depth interviews with the female defectors. Forty-four interviewees had more than fifty times in-depth interviews and each interview took average three hours.

Theses interviews were carried out by participating a research team for investigating the issue of North Korean city in the Institute for Far Eastern Studies at Kyungnam

3) This is women are less restricted to their jobs than their husbands who have to attend their offices even when they are not paid. And women have been in their side jobs through the home working party. For details see ref. 16.

4) Economic crisis puts economic responsibility on women's back, and strict division of labor according to gender was collapsed. However, women's role in household affairs and childcare still seems to be significant. And husbands are still recognized as their patriarchs although they are not objects of respect. Moreover, women tend to be still dependent on their husbands" social status although they take economic responsibility. For details refer to Lee, mi-kyung (2004), pp.183-212. 
University during the period from 2002 to 2004 to investigate the change of North Korean women's life and their awareness. Since this research is based on in-depth interviews of limited number of people, it is difficult to generalize the result of the research as the number of sample are only forty-four. However, the fact that the interviewees have different backgrounds in their hometowns, ages, and jobs offsets the weakness of this research. The interviewees are from Cheongjin, Shineuiju, Hyesan, Onsung, and Hamheung etc. And their ages are ranging from in their twenties to sixties: three in their twenties, fourteen in their thirties, seventeen in their forties, ten in their fifties, and seven in their sixties. Eight of them were laborers, two of them were the director of collective farms, three of them worked for service areas, eight of them were office workers, nine of them were professionals, five of them earned by foreign currency, and three of them were housewives.

In order to complement the weakness of in-depth interview, this thesis cross-checked the results of the interviews by reviewing the official documents of North Korea such as

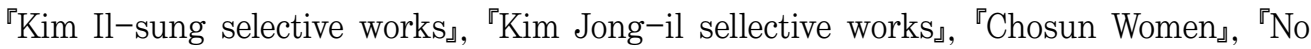
Dong Sinmoon」.

\section{The issues of North Korean Women}

\section{Gender Awareness of North Korean Women}

As generally well known, although North Korean women participate social and economic activities, their social status is not as same as that of men. Their official social status is as same as men, and they could access to every social opportunities in principle. However, their various activities did not lead their enhancement of their social status. It is basically caused by the government policy that does not intend to lead emancipation of women and enhancement of their right. Furthermore, deep-rooted Confucianism that prevails all over the society have discriminated women according to the division of labor by their gender. North Korean women had been recognized as subsidiary or substitutional worker who were assigned to jobs that require simple and easy works. ${ }^{5)}$ It is well shown that their jobs were concentrated on the agricultural labor,

5) According to the basic principle of labor distribution in North Korea, "Labor should be stationed considering people's gender, age, condition, and their skill. Women and weak people do easier work, but strong young men do hard work." "Social Science Academy of North Korea Economy Institute, Economy Dictionary. (Social Science Academy of North Korea Economy Institute, 1975), pp.608-9. 
light industry such as textile industry and services for convenience, commercial distribution, nurse, babysitters, public health, education, secretary and so on. ${ }^{6}$

In political perspective, women were in their inferior status compared to men. ${ }^{7)}$ North Korean law have stipulated legal political equality since the state established. However, in reality, North Korean women's participation in public affairs was basically related to their family and their loyalty, it did not lead to enhance women's awareness and their rights. ${ }^{9)}$ Actually, women's participation in politics was higher than that of South Korea accounting for 20.1 percent in supreme people congress representative, 20 percent in the 8th and 11.8 percent in 9 th representative. But, supreme people congress representative is symbolic, thus it does not have any controlling or supervising power and even could not criticize about political affairs. ${ }^{9)}$ The fact that there is no woman in political bureau or secretarial bureau that are essential power organ means women's participation in essential party is limited. ${ }^{10)}$ Therefore, women's participation in politics itself is apart from growth of their influence that make to politicalize themselves.

However, North Korean women does not have awareness about their reality that enforces subordinate status and overwhelming burdens. "Man and women is fundamentally different. ... man's duties and women's duties have been determined. ... This is a tradition of Chosun. ..." The North Korean female defectors have taken realities of gender discrimination for granted. ${ }^{11)}$ Furthermore, the North Korean women have passive awareness that they have thought of as beneficiary in spite of being criminated and having the double burden. In North Korea, women's participation in public affairs were considered as a kind of leader's grace not their voluntary choice or efforts. The North Korean women's social activities was focused as a major means to achieve equality to both genders and to revolutionize or armament them.

6) Korean women's Development Institute(1992), pp.203-8.

7) In North Korea, women's participation in public affairs is very active. According to the release of North Korea, 49 percent of total workforce, 70 percent of light industry, 80 percent of teachers in the primary school and 15 percent of professors were women in 1991. However, according to the interview with the defectors, 70-0 percent of women have quitted their jobs as economic crisis became severe. Therefore, the female workforce accounting for 49 percent of total labor force includes household work team. It means women had to be layout first while trimming of the personnel. In addition, the small rate of female in managers also indicates the discrimination on women. Kim, Kwi-ok (2000), p.42; Yoon, Mi-ryang, (1991), pp.198-205.

8) Sohn, Bong-sook, (1991), pp.257-59.

9) Jang, Pil-hwa, (1992), p.26; Jeong, Hyun-baek, (2001), p.90.

10) Oh, Yoo-seok, (2001), pp.342-43.

11) The Interviewer, Most of North Korean women defectors have thought of gender discrimination according to the principle of division of work by gender as accepted usage. 
However, women's participation in public affairs were actually to mobilize female labor force into social development strategy. As the economic structure of North Korea are based on labor-intensive industries, utilizing the female labor force that accounts for more than half of the total population was critical. ${ }^{12)}$ In North Korea, encouragement of women's work and its supports were concentrated into the period for socialistic economy construction, but withdrew when the operation rate decreased since 1980s.

In this point, women's social activities were their duties to carry out in terms of reward for the leader's grace. Moreover, legal and systemic schemes that encourage women to work prevent women's awareness and even the necessity to be through make them to recognize themselves as beneficiaries. Accordingly, North Korean women carried out their duties without any awareness since women's participation in public affairs originally did not intend to enhance women's awareness.

Accordingly, North Korean women thought themselves as mother or wife rather than achieving their own goal although they participated in social affairs. Basically they have priority over their husbands and children. They thought that they have to support their husbands faithfully, and eighty to ninety percent of their husbands success depends on the efforts of the wives. They thought that father' s success should go in advance for the success of their children even though their husbands do not earn a money. ${ }^{13)}$

In this manner, as North Korean women accepted the traditional gender role, they thought household affairs and childcare are wholly responsible for themselves. Although they did not think they were dissatisfied with the fact that their husbands did not help them, they did not think that is a problem. ${ }^{14)}$ This shows that their discriminative gender awareness did not changed much although the economic crisis had changed their life patterns.

\section{The change of North Korea women's awareness and its limit}

The economic crisis brought tremendous change in their life and awareness. The

12) In North Korea, the ratio between men and women was fifty-fifty right after the emancipation in 1946. Since the Korean War to 1963, the number of women surpassed that of men (In 1953 men accounts for 46.9 percent, women 53.1 percent. In 1963 men accounts for 48.7 percent and women 51.3 percent.) Hereafter the ratio of men and women became to be paralleled and in the 1990s the ratio of women increased. Kim, Ae-shil, "Women's economic activities", Son, Bong-suk et al.,(1991), pp.175-78 .

13) A women from Cheongjin in her sixties who were a office worker, and a women from Cheongjin in her forties who worked for a nursery school.

14) A women from Cheongjin in her forties who was a teacher, a woman from Hyesan in her fifties who were laborer, and a woman from Shineuiju in her thirties. 
difficulty began to be embodied from 1980s, and it was more accelerated in 1990s. Thus the people of North Korea had to work out for their salvation by their own efforts. Accordingly, the changes over the whole society influenced women's life and awareness and women had to take major responsibility in their livelihood. ${ }^{15}$ ) Undoubtedly North Korean women participated in public affairs through full time or part time job before the economic crisis but after the crisis they had to take a full responsibility. While men had to go their offices although factories or offices stopped and were not paid properly, women were rather free in shifting their jobs. ${ }^{16)}$

As discussed above, prior to economic crisis North Korean women had to carry out their role as a traditional woman under patriarchism irrespective of their social status. However, as the economic crisis broke the food supply system, household livelihood could not be sustained with the distribution and salary of their husbands. Therefore, women began to work actively for their living, so women's role and status started to change and their awareness as well. Before the economic crisis the roles between male and female were strictly separated under the structure of dividing labor according to gender, therefore every women had a full responsibility in household duties and rearing. However, women had to leave home for a long time to find food after the economic crisis, and the number of men who did household duties and rearing increased. ${ }^{17}$ After the economic crisis, men who watch their house like a dog increased, and they voluntarily did household duties and helped their wives who did their business. ${ }^{18)}$

In short, North Korean women experienced a tremendous change in their previous awareness that they had to subordinate to patriarchical system that strictly had divided

15) After the official supply system was stopped, the people of North Korea had to cultivate the soil, do their business or earn foreign currency to sustain their livelihood. The others who even do not afford to do these works, they had to sell household goods, gather grassroots, pine peels or beg. However, most of them maintain their livelihood by doing businesses. Undoubtedly there are various kinds of businesses in their scale and feature; from selling household goods for their food and selling bread, bean curd, and noodle based on the capital that they could earn by selling their household goods to earning foreign currency.

16) As women already had been worked as a means of a side work through household working groups manual industry or business, they could easily transfer to full-time worker to maintain their livelihood. However, the reason women do their business for maintaining their livelihood rather than men was the remained tradition of Confucianism. An early 40s woman from Hye-san who do office works said "Women could sell anything, but men couldn't. North Korean men regard selling as a shameful work. But they could do best smuggling at night.

17) Korean women's Society Institute, (2001).

18) An early 30s woman from Hye-san who do office works said men used to give orders at everything. But they are like a lamp at daytime since they are not what they used to be. And they became kind to their wives and even support them." 
their roles according to genders. Although this change agitated the patriarchical system, however did not reach for women to recognize their conditions. For sure, they did not stick to a strict labor division between male and female, but they still think women have more responsibility in household duties and did not deny their husband as a patriarch and their authority itself. These facts have been testified through in-depth interviews. The survey had seven questions concerning the change in women's role and awareness.

The following seven questions were used for the interviews to analyze the change of the role of women at home or their awareness after the economic crisis. (1) Who was responsible for their livelihood? (Respondent herself, Husband, Collaboration) (2) Who was the major taker of the household duties? (Respondent herself, Husband, Collaboration) (3) What do you think of your life itself if women take most of the responsibility for their livelihood? (It is women's natural responsibility. It is undeserved since it is husband's duty. It is unescapable.) (4) What do women think that their husbands do household duties? (It is natural. It is unescapable. It seems to be sorry.) (5) Do you think you have to revere and support your husband? (Yes, No, I don' t know), (6) Do you think women had to take the whole responsibility in fostering peace in their family such as educating children or supporting their parents-in-law. (Yes, No, I don't know) (7) Do you think the role of husband and wife is fixed at home? (Yes, No, I don't know)

According to this survey, a strict labor division between male and female was broken down, but not enough to deny and break the patriarchical system. In a question who took the major responsibility in rearing, most of the women answered they has more duties than their husband, and only a few answered 'women'. ${ }^{19)}$ Among the forty-four interviewees, twenty-four of them answered both husbands and wives were responsible for their livelihood, and nineteen of them answered that wives were wholly responsible for their livelihood. However, sixteen of them answered that both husbands and wives were responsible for their household affairs and caring, and twenty-eight of them answered that only wives were wholly accountable for the family affairs and caring as same before the economic crisis. This shows that women still have responsibility in household affairs and caring while they contribute to their livelihood at the same time.

As North Korean women took a major responsibility in their household living, their

19) According to the interview with the female defectors of North Korea, there are two cases: first is that women took responsibility for the livelihood and household duties, second is both of wife and husband took the responsibility for their livelihood, but women had to take the whole household duties when the women were single or their husband was dead. 
fixed idea about labor division between male and female was broken. To a question that they think whether there is fixed role in their home, a majority of them responded "No". Thirty-three of forty-four female defectors answered that the roles of husband and wife are not fixed at home, and eleven of them replied they are fixed. Moreover, twelve of them answered that wives are wholly responsible for the education of children and the supporting their parents-in-law.

However, this change of their awareness is insufficient. In addition, they did not deny the authority of their husband as a patriarch although they are not devoted to their husbands. They even tended to depend on their husbands' status although they have their own jobs. Except for some well-educated most of the women wanted to marry men who could guarantee prosperous living rather than showing their ability. This shows the limit of change in their awareness and the level of their awareness that is subordinate to men and lack of awareness. ${ }^{20)}$

It is because the change of the role and status in their home caused the change of their living and awareness. It was apart from the change of their role in society. While the people had to live without the nation's support and women began to participate in public affairs, the society was managed under the principle of patriarchy and paternalism. It means that the changes in North Korea after the economic crisis was not enough to cause the fundamental shift in the political system of North Korea. Therefore, North Korean women accept the traditional role of women although they took the major responsibility in their household living and did not accompany with a change in their awareness about the current condition.

Furthermore, the limit of the change in their awareness shows the limit of their economic activities itself. It was enforced more by the nation's requirement and for their living rather than their by own choice. As the women's public affairs was not carried out spontaneously by their motives to achieve something, it was natural that such activities did not accompany with independent and active consciousness. Furthermore, the conditions that were enforced to them externally although the patriarchical system was maintained were really afflictive. These are testified through the interviews with the female defectors of North Korea. Although North Korean women recognized their dual burden in society and home, they tried to evade the burden by giving up social activities. Married women had difficulty in finding jobs because companies avoided them, but in many cases women did not work after their marriages. Undoubtedly most

20) The following testimony shows well such a situation. A female worker in her early 30s from Hye-san said "My hope is to marry a man who earns a lot of money and live comfortable." "Sewing at home is elegant rather than deal in at market." 
of these cases fell under women who did simple works rather than well-educated professional women. Considering the ratio of well-educated professionals is small, participating public affairs is beyond their capacity for North Korean women. Therefore, social activities of North Korean women did not accompany with an equal status and active awareness since the political system did not change fundamentally even after the economic crisis.

This issues on the North Korean women, their passive attitude and their lack of awareness was caused by the political features of North Korea, especially by its policy and ideology that make women's awareness insensible for a long time. Definitely it will analyze what were specific measures they used to prevent women's awareness, and the process of women's non-awareness led by the government policy.

\section{State and Woman}

\section{North Korean Women under patriarchal socialism}

The realities that the North Korean women have passive awareness in spite of having the subordinate status and dual burden that is caused by the characteristics of political system. In North Korea, women were recommended to equally participate in revolutionary struggle and the construction of socialism, simultaneously emphasized the role of traditional women. Accordingly North Korean women are required to participate in various social activities and at the same time to be a good wife, daughter in law, and mother. This is originated in paternal patriarchal socialism that officially advocate 'gender equality', but tactually emphasize the role of traditional women.

One of the most distinctive characteristics of the political system of North Korea is that the supreme authority of the leader 'Suryong' in every domain, such as ideology, laws, administrations, regulations, process and so on. ${ }^{21)}$ Such a 'Suryongje' (a system dominated by the supreme leader)or 'Yuil cheje' (a monolithic system) that only admits the control of Kim Il-sung and Kim Jong-il definitely reveals the rampant characteristic of North Korean society. The 'Yuil cheje' reconstructed the whole society with a great emphasis on 'Suryong' based on theories that rationalize the system such as the view of revolutionary suryong, the theory of social political life, the theory of heraditary power

21) One of the most noticeable features is Suryong system or monolitic leadership system that the authority of the highest leader, Suryong stipulates ideology, laws, systems, and regulations. Masayuki Suzuki(1992), pp.71-102. 
succession and other theories that put into practice such as absolute authority system, social mobilization system, cult of personality. ${ }^{22}$

The view of revolutionary suryong, which is the theocratical base of the sole leader system that stipulates the status and the role of 'Suryong'. According to the definition of the view of revolutionary suryong, the status of Suryong is explained as "the brain of the masses, the center of unification, and the supreme leader of revolutionary struggle for independence". ${ }^{23)}$ And the role of Suryong is defined as "to create the revolutionary ideology that definitely reflects the demand and interest of the masses and brighten the road of revolutionary struggle ahead. ${ }^{24)}$ Therefore, Suryong is the absolute being and all the people including women are the passive being. As for the people of North Korea, Suryong is the brain in a organization that controls everything reflecting the demand of the people, then tell them how to practice it. Thus, the only thing that people have to do is just to follow Suryong.

However, the people of North Korea are defined as "the subject of revolution and the decisive factor that reconstruct nature and develop the society" ${ }^{25)}$ It is based on the philosophical principle of the Juche Ideology explaining "the masses are the master of everything, thus they have the authority to decide everything" for their intrinsic characteristic such as independence, creativeness, and consciousness. Also it is on the basis of the socio-historical principle. But, the masses have to be under the leadership of Suryong so as to carry out their duties. According to stipulation that "For the masses to lead their history, the leader and the masses should be combined", Suryong is the subject of guidances. ${ }^{26)}$ Accordingly the stipulation that the masses are the subject of history that is completed by the guidance of Suryong. In the long run, it comes to a conclusion that the North Korean people have no choice but to abide by the guidance of Suryong even when they display their abilities and fulfil their duties.

This logic is justified and reinforced by the theory of social political life that is the another theoretical ground of 'Yuil cheje'. The theory of social political life is derived from the view of revolutionary suryong and it compares the social system to a family. As a family is based on the relationship by blood and integrated organically, the society has father Suryong, mother party, children the masses. ${ }^{27)}$ In this context, 'political life'

22) Jong-seok Lee(2000), pp.101-53.

23) Chang-ha Kim(1985), p.199.

24) Chang-ha Kim(1985), pp.201-2.

25) Kim Jong-il(1991), p.182.

26) Seung-deok Park(1984), p.151.

27) The theory of social political life basically starts from the dichotomy of lives. There are two kinds of lives; physical life and political life. The latter is more important and Suryong gives 
makes the social organic to live as a social being focusing on Suryong. "In the light of the theory of social political life, Suryong is the life spring" "As the brain is the center of an individual, Suryong is the center of the theory of social political life." As above two definition is revealed, Suryong gives political life to the masses. Accordingly, Suryong, party and the masses have the relationship by blood, and the masses should absolutely obey Suryong since Suryong gives all the rights to the masses and controls the masses. This discourse of socialism and family explains the family consciousness that is applied as a controlling theory in the society of North Korea.

Considering the characteristics of Juche Ideology that has dominated North Korea, the status and the role of women is evident. There are two theories that explains such characteristic: the view of revolutionary suryong that puts Suryong as an absolute ruler and the theory of social political life that Suryong is represented as the life and the role of the party and the people. According to theses theories, the identity of the people is defined as giving their fealty to Suryong. This logic is requoted by the principle of confucian patriarchy that North Korea reinterprets such traditional filial piety and loyalty ideology as people's duty to the leader. People's devotion to their father Suryong seems to their duty of a child and people and the image of the chief of a family is applied to the nation's Suryong. ${ }^{28)}$

Therefore, North Korean women have to participate in social economic activities as the subjective of revolution and construction and faithfully obey Suryong as their patriarch of the country and they have to respect their husbands at home. They are being required to participate in social activities according to the principle of Socialism, but they are also being required to raise their children and respect their husbands. ${ }^{29)}$ It means that North Korean women are doubly burdened with the double roles as the society compels women as its revolutionary worker and the traditional role of women.

However, North Korean women are under the structure that obstructs their realization of the situation. The yuil cheje' (a monolithic system) makes the people including women to be passive, therefore the people have to obey the dictation and requests unconsciously. Thus, raising issues against the leader and the regime is obstructed in

this life as the center of this life. Suryong, party and the people are tied with blood relations and the people are required to be devoted to Suryong to their 'Father Suryong' who saved their lives. The Social Science Publishing House, Series of Juche Ideology 2, Socio-Historial principle of Juche Ideology, (Backsan Seodang, 1989).

28) Family in North Korean society means the minimum unit for production as cell of society and at the same time it changed into traditional and instrumental means as a learning ground of socialism, then caused a new patriarchical socialism. Park, Hyun-seon(2003), pp.43-4.

29) Hyo-jae Lee et al. (1999), pp.426-67. 
advance as Suryong-Party-the People are destined to be a community. Therefore, North Korean women accept the ironical reality of life uncritically thanks to the characteristic of political system that compels the people to be devoted.

\section{The North Korea's policy on women: paralyzing awareness}

\section{1) Maternity Ideology}

The conformable mentality of North Korean women that is caused by the characteristics of political system is more consolidated by North Korea's policy on women. The policy is based on a double principle that they officially advocate 'gender equality', but they actually emphasize the role of traditional women. Accordingly North Korean women are required to participate in various social activities and at the same time to be a good wife, daughter in law, and mother. Evaluating the overall policies of North Korea on women, they actively encourage women's social activities in the beginning of the regime, however, they emphasized a patriarchal system as 'Yuil cheje 'the monolithic leadership system) had been formed. Since the 1980s, the role of traditional women has been more clearly restored. ${ }^{30)}$ The role of traditional women has been always emphasized, especially since the crisis began to be embodied from 1980s. Due to the economic difficulty, managing social welfare system was frustrated, then the responsibility of the party and the country was consigned to individual families. In order to lessen the burden of the country, the traditional role of women that demands women's sacrifice and devotion was enlarged from families to society. ${ }^{31)}$

Such a change in policies basically aims at the need of the government not the development of women's right. North Korea had carried out series of policies to mobilize women's labor force that hold more than half of the whole population. It is evident that women's social activities were vivid when the government requires women's work force. North Korea enacted laws containing equality of both genders with an emphasis on the illiteracy eradication campaign and propaganda cultural project. They are 'Act on land reform' (1946.3) that aims to distribute the land equally to both men and women, 'Law

30) Jeon, Sang-in(1993), pp.1-5.

31) In the 1980s North Korea suffered from economic difficulties, then women's labor is based on sacrifice and devotion was more required. In particular, as kinds of social security systems stumbled due to the stop of the official supply system, the burden was shifted to women expending their role from women as mother, housewife, and daughter in law at home even to mother of the whole society to care for military, orphans, old people and so on. Accordingly, relief business and caring for orphans and old people were recommended, then the journal "Chosun Women" deals with such issues substantially from the middle of 1980 s to the 2000 s. 
on labor workers and office staffs' (1946.7) that guarantees equal economic activities to both of them, 'Act on the equality right of both genders' (1946.6) and 'Law on social insurance' (1946.12) that stipulates equality in the whole sector. These are to reform the feudalistic relationship between male and female, and enhance women's rights and interests by abolishing vestiges of capitalism, at the same time to join women into the working field.

Their participation was conspicuous at the restoration period after the korean war, and socialistic economy construction period-the 3 year economy plan since 1954, and the 5 year plan since 1957. During these periods, North Korea proclaimed establishment of socialistic industrialization, collective agriculture, reform plan on commerce and industry aiming at building the basis of the socialistic industrialization. Accordingly, North Korea unfolded kinds of policies to construct the great Socialism while encouraging women to participate. The government also tried to increase child-care centers and kindergartens and constructed various food factories in order to facilitate their participation. ${ }^{32)}$ These facilities helped women concentrate their works as their contribution increases. ${ }^{33)}$

As a result, these measures activated women's participation to society, then the ration of women in the whole labor force accelerated. ${ }^{34)}$ Women's activities were emphasized officially as a premise of women's emancipation, however, it aims to mobilize women into economy construction. And various supports and arranging legal and systemic mechanism has an intension to attract women into society as well. ${ }^{35}$ As mentioned

32) Since the regulation on the establishment of child care center on February 11949 child care centers had established at factories and companies. And the number was accelerated after one center had established at each region since 1958. Even some nurseries where children stays six days and be brought to home at weekends were prepared in each province, city, country. And some monthly based nursery for dispatched people for long term, or entertainers for tour concerts was also prepared in Pyongyang, Gaesung, Cheongjin and so on. Oh, You-seok? Koo, Sumi,(2004), p. 215.

33) Such series of systems did not implemented over the whole region, moreover, it did not last long. According to the testimony of the defectors, theses facilities were not used so much, and particularly concerning the rice factory, the quality was worse and the quantity was less than those of home. Therefore, people did not use the rice factories due to the high cost and long distance, just use them when it comes to noodles and so on. Kim, Ae-shil(1992), p114.

34) During the period from 1956 to 1964 when the establishment of socialism got into strides, the number of female employers had increased 4.7 times more by an average of 19.4 percent compared to that of male 1.9 times more by 8 percent. In 1972, female employer accounted for 49 percent of the manpower in North Korea. Kim, Ae-shil, (1992), pp.187-88.

35) Using female labor does not stop inputting their labor into society. The government intended to utilize the idle production capacity that includes women who is over their 55 through organizing "domestic factories, 'domestic cooperative association. 
earlier, encouragement of women's work and its supports were concentrated during the period for socialistic economy construction, but withdrew when the operation rate decreased. Since North Korea went into economic recession, women have been enforced to be labourers and good mother, wife, law-daughter etc, traditional women at home at the same time.

Moreover, it is evident that women's social activities were granted from the leader nearly compulsorily not from their own will. ${ }^{36)}$ In North Korea, not only women, but nearly all the people have to follow the party's plan when they work. Their hopes and aptitudes are considered, but their family background, loyalty to the party, personal acquaintance with party executives play more important role. Moreover, women are discriminated, therefore their works are inevitably concentrated on light industries, education, and health. ${ }^{37}$

Therefore, it is testified why North Korean women's status has not enhanced although their active participation in society. Also North Korea emphasized a maternal ideology in order to justify using female labor force corresponding to the necessity of the nation. In general, maternity ideology has been functioning as the mechanism of oppression and restraint of realm of women's life but the North Korea's maternity ideology do not impose restrictions on women's activity. The North Korea's government encouraged and supported the women's social activity in spite of considering and making account of maternity as what the women should do.

As mentioned earlier, maternity has been consistently stressed in North Korea as a fosterer of members of the society in order to be equipped with the requirements as a member of the society. However, the role of maternity requires multidimensional tasks that had to carry out everything as a fosterer in the society. Accordingly, North Korean women had do their both role giving their fealty to the party and the leader, puting into practice collectivism and had to be leading fighters to revolution and construction

36) It was inevitable for women to work after graduation since it was mandatory to be assigned, and they were not provided with food if they did not work. Furthermore, they were encouraged to participate in society since it was regarded that it could enable women's emancipation and promote their position.

37) According to the decision of the cabinet in 1958, they determined the ratio of women in education, health to be over 60 percent. In addition, Chosun Central Year Book says women were assigned to do office work, light labor considering the individual characteristics. And men were assigned to mining, lumbering, manufacturing iron that are important and tough jobs. Actually, in the early 1970s, female labor is concentrated on light industries by 70 percent, teachers by 80 percent, and agriculture by 60 percent. North Korea Compendium. the middle volume,(1983), p.220.

38) A subjective communist is ideal person that is made by the Juche ideology, also a realistic goal of all the people must be. The prime virtues are loyalty and filial piety to Suryong. The 
struggle. ${ }^{38)}$

Likewise, the maternity ideology of North Korea assuming kinds of roles has given a big burden to an individual woman, however it is justified as mother's essential role based on sacrifice and devotion. It means that women had to carry out different mother' s role corresponding to the social situations. Therefore, the maternity ideology that has been applied to society is deemed to maximize women's labor force and justify their intension.

As a result North Korean women considered their situation as reasonable without any critical sense. Therefore, North Korea's policy on women adhered actual discrimination causing women's subordinate position and passive consciousness although it proclaims equality on both genders.

\section{2) Ideal model of women}

Another means of socialization that made the North Korean women members of the society, passive being who have to obey the dictation unconsciously is an ideal model of women. An ideal model of women that requires women to follow is a woman who successfully carry out multiple roles which the system of North Korea encourages or needs. ${ }^{39)}$ Such emphasis makes North Korean women to be insensible their criticism as their duties were accepted plausible. Therefore, an ideal model of women could be examined through considering what the country specifically requires and how women's awareness could not grow. Followings will consider theses things with an emphasis on Chosun Women that is a representative literature. ${ }^{40)}$

people are armed with revolutionary justice and camaraderie and a hero who adventures his or her life on their group is the only subjective communist. Such a subjective communist is presented a new type based on the prior principle of reconstruction of public thought. They recognize their duties and roles in the social and political life, and devote themselves to a common great work. Lee, Jong-Seok,(2000), pp.227-230.

39) In North Korea, women are required to participate in public affairs, but they also have to be a traditional women in patriarchy. For example, they have responsibility to make peace in their family and to have well-featured face as well. The tone of Chosun Women is generally based on this requirements. One of them is "...Women's struggle for achieving their rights is important...but, women do not have to forget women's own characteristics while they are trying to struggle for their emancipation and rights. Women should be womanly...", "Women should be womanly' Chosun Women 1989/04.

40) Chosun Women has been published monthly since September 1946. It was firstly decided on May 10, 1946 to awaken North Korean women who had been in a feudalistic idea and illiteracy, then mobilize to national affairs. From 1983 to 2000, it was published every other month, and from 2001, it was published monthly again. This magazine was a representative of chosun democratic women's union of North Korea and it mainly contains policies of the parties and political power, and good examples of women to enlighten and educate them. 
An ideal model of women that leads women to be numb is based on 'juche type' human being who do social activities and household duties simultaneously with their devotion to the leader, party and their country. Accordingly, the role model basically means women who give their fealty to the leader Kim Il-sung and Kim Jong-il and their nation. Among the devotion to three things, leader, party and country, the loyalty to the leader have the priority to other things. This is very plausible considering the political system of North Korea, however it justifies people's devotion to the leader based on these two things. First, loyalty to the leader is considered in return for the leader gave them emancipation and enhancement. Second, women's emancipation and enhancement of their status was plausible in the view of revolutionary Suryong.

Based on this, Chosun Women mentioned a lot of cases and essays of gratitude that women actively participate in various public affairs since the leader Suryong emancipated women from series of traditional subordination. ${ }^{41)}$ Also, their absolute loyalty is justified based on the view of revolutionary Suryong and theory of social political life. Hence, their loyalty to the leader blocks dissatisfaction and questions on their society in advance.

Second, the ideal role model of women is who execute their 'totalitarian ideal that individual woman look out for the group and the group for the woman. In North Korea, individualism and egoism are rejected and communistic morality that enforces absolute devotion for group or society is emphasized. ${ }^{42}$ There are various cases that reflects collectivism that focuses to give up individual's right since it is less meaningful than the group. Taking care of parentless children and old people by joining them to their family, being a wife of a honorable soldier, participating relief business and so on. These cases are all make North Korean women to carry out what North Korean society requires from time to time.

For example, during 1960s and 1990s the administration was military oriented due to the economic and security crisis was accelerated, the government encouraged women to actively participate in relief business. There are various examples of the relief business such as "wife of the people's army", "the mother of the people's military" who produce

41) There are several essays expressing their gratitude to their leader such as 'In order to emancipate women from household duties' (1977/04), 'He gave us equality on both sexes' (1979/07), 'A benefactor for women's liberation' (1980/04), 'The lord of the nation and the pillar of the revolution' (1985/02), 'He treats female worker well' (1991/02), 'For housewives to work more delightedly and easily '(1993/03), 'He supports women as the leader of the nation' (1993/05), 'North Korea is a paradise for the people, especially for women' (1993/05), 'He raised us as a good female worker' (1998/03).

42) Lee, Sang-hwa, (1996). 
military uniforms, weapons and munitions or distribute food by farming or raising cattle. And even in crisis they had to be a female warrior. ${ }^{43}$

After 1990s, women were much more enforced to follow the collective ideal as North Korea fell down to a crisis on the whole. The economic difficulty made the official supply system stop and most of social security system not work properly. Thus the government attributed the burden of the failure to individual households. For instance, individual household had been recommended to take care of orphans, old people who live alone, honorable soldiers and so on applauded as 'hidden patriot-the mother of communism', 'the noble spirit' and 'happy family' and so on. ${ }^{44}$ Such a trial aims for women to carry out their roles more aggressively encouraging their activities are heroic by expanding their roles as a mother into society.

Another ideal role is woman who works. In North Korea, women were recommended to equally participate in revolutionary struggle and the construction of socialism quoting "A cart does not work well if one of the pair does not work well". Women's participation in public affairs was focused as a major means to achieve equality to both genders and to revolutionize or armament them. However, women's participation in public affairs

43) There are several essays that emphasizes encourage relief business such as 'member of the women's union who helped the people's army in devotion' (1967/07), 'wife of the honorable soldiers' (1967/10), 'I will be a mother of the children' that encourage to raise orphans as their real children(1974/01), 'A mother who sent her seven sons to guard posts' that praises a mother who sent his all sons to the army' (1974/02), 'Women in Soksa ri who flighted supporting the battle' that women of a village supported the people's army during the Korean War, 'She was a housewife' (1993/03) that introduces an episode that a woman flighted in a military uniform for the party and the leader, "A reliable mother to the soldiers' (1993/05) that introduces a woman who loves the people's army and relieves them, 'In meticulous mother's heart at hometown' (1993/03) that emphasizes relief work toward the people's army, 'Help our army-support the soldiers in relief work-in each women's union' (1994/06) that focused women' s role in the relief work, 'I will live as a mother of the people's army' (1995/03), 'Caring soldier' s living thoroughly' (1996/02) that emphasizes the behaviour of Madame Kim Jung-sook who coincide the people and the people's army, 'Supporting the family behind-from the beginning class of women's union at the Dongheung Mt. in Ham-heung City-' (1998/05), 'Mother in Eui-ju who loves soldiers'-Kim, Young-soon, (1999/03).

44) This is shown well in Chosun Women. 'An idea about a worthy women' (1987/05) that express a woman who took care of a honorable soldier and married him as a woman who has noble spirit" and praise her. "A hidden patriot-a mother of communism-a story about a woman, "Kim, Ok-hwa at Mankyungdai dong who raised fourteen bereaved children of patriots- '(1990/01) that praise a woman who adopted the bereaved children as the instruction of Kim Il-sung indicates that someone who sympathize other's sufferings and help them will be a genuine communist. 'A happy family-finding the home of Han, Aesook, a commissioner of women's union in Pengsankun Walchunri' that introduces a family that put into practice the laudable custom of communism by taking care of parentless children and the old people who did not care for them. 
were actually to mobilize female labor force into social development strategy. As the economic structure of North Korea are based on labor-intensive industries, utilizing the female labor force that accounts for more than half of the total population was critical. Moreover, women's social activities were their duties to carry out in terms of reward for the leader's grace. Therefore, legal and systemic schemes that encourage women to work prevent women's awareness and even the necessity to be through make them to recognize themselves as beneficiaries.

Lastly, an ideal woman in North Korea is a woman who carries out her traditional role as a woman. As mentioned above, the foremost and basic duty of North Korean women is traditional role of women including maternity. The emphasis to carry out traditional role of women was natural considering the features of North Korea's political system and it basically based on the theory of socialistic family. Seeing in the mottoes such as 'Family is the core of society', 'Family is the smallest cell in the country', society and family are inseparably related each other. ${ }^{45}$ This is based on the theory of socialistic family that family has duty to carry out its responsibility toward society while the country has responsibility to take care of family. Under the such mutual relationship, family also has to raise their children well. ${ }^{46)}$

Therefore, women's traditional role was emphasized, especially the importance of maternity. ${ }^{47)}$ As for North Korean women, the emphasis on maternity is found through all over the time. Particularly, entering into 1980s it is focused more in relation to the process of theoretic systemizing Juche ideology to rationalize Yuil cheje(a monolithic system). In particular, 'the theory of social and political life' that is based on the people's 'blood relation' or 'revolutionary faith and compatriot' to make a grand family of socialism owns the same thread with Confucian patriarchy.

Furthermore, the traditional role of women was more emphasized after the economic crisis. It is to rationalize for the country to avoid their duties such as basic living and various social safety net to individual families. This aims for women to accept their duties without criticism emphasizing the role of maternity such as sacrifice, devotion as an intrinsic duty of women. In short, an ideal model of women that requires women to

45) This provision is stated in the Article 63 of the Communist Constitution. A complete collection of laws and regulations of North Korea.

46) Jeon, Sang-in(1994); Park, Hyun-seon(2003), pp.52-52.

47) Chosun women has substantial articles that emphasizes maternal status and role among the traditional role of women. There are various themes; emphasizing fostering communistic people whom the regime of North Korea requires in the revolution and nation building task; suggesting the way to raise children by step; culture and knowledge for parents to have in fostering their children; focusing the importance of family. 
follow was a mechanism to make women to be numb in recognizing their confronting circumstances.

The North Korean women were disturbed to have awareness about their unreasonable conditions while they have been suffering from gender discrimination and restraints and it was systemized since the construction of the regime. As a result, the lack of awareness of North Korean women was not improved although overall changes were proceeded after the economic crisis. Although economic crisis made women not to depend on their husbands, and there were some changes in their life and awareness, they were still remained subordinate position and passive awareness. It means that they were acclimated by the policy that did gender discrimination and restraints that interfered them to have awareness.

\section{Conclusion}

This research was started from a question whether North Korean women have equal status corresponding to their participation in public affairs and active awareness. And it aimed to figure out what is their problems and the cause of the problems by examining gender awareness of female defectors of the North Korea. North Korean women have accepted their conditions without awareness having a double burden with social mobilization and coerced labor under the sexually repressive and discriminative social environment. They have participated in public affairs in legal and systemic support under the principle of sexual equality since they had established the regime. However, they had to carry out both of their social and household duties having a full responsibility in household duties. Furthermore their participation was a coerced labor not for their self-fulfillment but for the necessity of the nation. In addition, they were discriminated in their wages compared to male workers and their works are concentrated on low-waged and low-leveled jobs, to their social status does not accord with the principle of equality of both sexes.

However, their problems do not end in their overloaded burden and subordinate status, but their awareness that could not criticize their current conditions. The interviews with the female defectors indicates that they accept their burdens and subordinate status as plausible. Although they were encouraged by the principle of equality to both sexes to participate in public affairs, they are lack of awareness why such ironic situation occurred and how to overcome this situation. Likewise the lack of political awareness is the fundamental reason for North Korean women. The lack of awareness is hard to 
resolve North Korean women's problems in short period of time. It is demonstrated that there was no shift in their awareness such as critical awareness and comprehensive denial over patriarchism while women's status and role were changing after the economic crisis.

The lack of their awareness and limit of the change was originated in the feature of North Korea's political system, but it is also a result that they had been tamed by the political culture that reproduced political unconsciousness and ideology. Officially they professes equality on both sexes, but they were enforced traditional roles as a woman under the patriarchical socialism. Therefore, they have carried out various roles corresponding the change of the policy. For instance, maternal ideology that justify their combined duties at home and society and ideal women model that encourages North Korean women to carry out their role successfully and finally blocked for them to be aware of their condition. Thus in order to resolve this problem the lack of political awareness should be considered with the change of North Korea's political system as it reflects the policy on women. 


\section{REFERENCES}

Cho, Hyung, "The Social System and Patriarchy of North Korea", Women Research Institute of Ewha Womans University, A view of women in North Korea. Ewha Womans University Korea's Women Research Institute, 1992.

Chosun Democratic Women Association, Chosun Women 1946-2003.12, Pyongyang: Workers Association Publishers.

Economy Research Institute, Social Science Institute, Economic Dictionary. Economy Research Institute, Social Science Institute. 1975.

Homeland Integration Institute, The Statute Book of North Korea. the first volume Seoul: Continent Institute. 1990.

Im, Soon-hi, Food Shortage and the Change of role \& awareness of North Korean Women. Seoul: Korea Institute for National Unification. 2004.

Institute for korean women society, The lives and dreams of North Korean women, Seoul: Social Culture Institute. 2001.

Jang, Pil-hwa . "Labor distribution between male and female in North Korea”, Ewha

Womans University Women Research. The view of Women in North Korea.

Seoul: Ewha Womans University Korean Women Research Institute (1992).

Jeon, Sang-in, The change of North Korea's policy on family. Seoul: National Integration Research Institute. 1993.

Jeong, Hyun-baek, Focus on North Korean Women, how to meet them. Seoul: Women and Society. 2001.

Kim, Ae-shil. "Women's economic activities." Sohn, Bong-sook et al. Women's living in North Korea. Seoul: Nanam, (1992).

Kim, Chang-ha, Immortal Juche Ideology. Pyongyang: Pyongyang Publishers. 1985.

Kim Jong-il, "About Juche Ideology", Kim Jong-il sellective works. The Institute for Far Eastern Studies at Kyungnam university. 1991.

Kim, Kwi-ok et al., How North Korean women live?. Seoul: Dangdae, 2000

Kim, Son-wook, A research on the status of North Korean women: focusing on the laws and policies on women. Korea Women Development Institute, 1992.

Kim, Tae-hyun, Rho, Chi-young. The Life of Female Defectors of North Korea in China. Seoul: Hawoo, 2003.

Korean Women's Development Institute, A study on the role and the status of North Korean women.' 92 Research Paper 200-6. (1992). 
Lee, Keum-soon, "The Realities of sexual discrimination of North Korean and its outlook". Unification studies. Seoul: National Intetration Resesrch Institute. (1996).

Lee, Hyo-jae, · Park, Hyun-seon. "Women and Integration", Institute for korean women society, Rewrite women \& korean society. Seoul: Social Culture Reseach Institute. (1999).

Lee, Jong-seok. A new understanding about Modern North Korea. Seoul: yeosabipengsa, 2000.

Lee, Mi-Kyung, "The change of living of North Korean women and their awareness after the economic crisis: focusing on the in-depth interview with the female defectors of North Korea", Asian Research Center, Korea University, The Journal of Asiatic Studies, 47-2.(2004).

Lee, Sang-hwa, "Ethnic view of North Korean Women”, "Comparison between women' s living of North and South」The fourth Unification studies arcademic semminar working paper 1996.12.9

Lee, Tae-young, A study on North Korean women. Seoul: Homeland Integration Survey and Materials Office, 1979.

-----, Women's living in North Korea. Central Association for National Integration, 1981.

-----, North Korean Women. Seoul: Shil-cheon Moon-hak sa, 1988.

Minister without portfolio room. The reality of North Korean Women. A research paper. Minister without portfolio the second room. 1990.

Moon, suk-jae. North Korean women and their home living. Seoul: Symposium for women's study, 1994.

Nam, In-sook. The reality of North Korean women. Seoul: The headquarter of Association of Korea's wives, 1992.

Oh, Yoo-seok - Koo, Sumi, "Women's living and the change of their awareness", editted by Choi, Wan-kyu, Formulation and Development of the cities of North Korea: Cheong-jin, Shin-eui-ju, and Hye-san. Hanul Academy, (2004).

Oh,Yoo-seok. "Preparing the political platform of women toward integration" Comparison between women's politics on North and South- Woon-Taek-rim et al. The Future of Integrated Korean Peninsula made by women. Thinking Tree,(2001).

Park, Hyun Seon, "A study on the status and the role of North Korean women: 1945.8-1947.2", Master's degree thesis of Ewha Womans University, (1988). 
-----, Modern North Korean society and family. Hanul Academy. 2003.

Park, Seung-deok, In-depth development of Juche Ideology. Pyongyang: Social Science Publishers. 1984.

Rho, Ok-jae,"The Life \& Human Right of North Korean Women in Food Shortage", The Life \& Dream, Bitterness of North Korean Women. Seoul: Council for Democratic \& Peaceful Unification. 2003

Sohn, Bong-sook, Lee, Kyung-siik, Lee, On-jook, Kim, Ae-shil, Women's living of North Korea. Seoul: Nanam, 1991.

Sohn, Bong-sook, Women in North Korea: Their living spot. Seoul: The public information bureau, 1993.

Suzuki Masayuki. North Korea-Sympathy with Socialism and tradition. Tokyo University Publishers. 1992. [Yu, young-koo(trans.), Kim Jong-il and suryong socialism. JoongAng Ilbo Publishers, 1995]

The Institute for Far Eastern Studies, North Korea Compendium. the middle volume, The Institute for Far Eastern Studies. 1983.

Women's study at Ewha Womans University. Integration and Women: The living of North Korean Women. Ewha Womans University Publishers, 2001.

Yoon, Mi-ryang. North Korea's policy on women. Seoul: Hanul, 1991. 